\title{
Smoking, alcohol and opioids effect on coronary microcirculation: an update overview
}

Zahra Jalali ${ }^{1,2}$, Morteza Khademalhosseini ${ }^{1,3}$, Narjes Soltani ${ }^{1}$ and Ali Esmaeili Nadimi ${ }^{1,4^{*}}$ (i)

\begin{abstract}
Smoking, heavy alcohol drinking and drug abuse are detrimental lifestyle factors leading to loss of million years of healthy life annually. One of the major health complications caused by these substances is the development of cardiovascular diseases (CVD), which accounts for a significant proportion of substance-induced death. Smoking and excessive alcohol consumption are related to the higher risk of acute myocardial infarction. Similarly, opioid addiction, as one of the most commonly used substances worldwide, is associated with cardiac events such as ischemia and myocardial infarction (MI). As supported by many studies, coronary artery disease (CAD) is considered as a major cause for substance-induced cardiac events. Nonetheless, over the last three decades, a growing body of evidence indicates that a significant proportion of substance-induced cardiac ischemia or MI cases, do not manifest any signs of CAD. In the absence of CAD, the coronary microvascular dysfunction is believed to be the main underlying reason for CVD. To date, comprehensive literature reviews have been published on the clinicopathology of CAD caused by smoking and opioids, as well as macrovascular pathological features of the alcoholic cardiomyopathy. However, to the best of our knowledge there is no review article about the impact of these substances on the coronary microvascular network. Therefore, the present review will focus on the current understanding of the pathophysiological alterations in the coronary microcirculation triggered by smoking, alcohol and opioids.
\end{abstract}

Keywords: Smoking, Alcohol, Opioid, Coronary microvascular dysfunction, Ischemic heart disease, Myocardial infarction

\section{Background}

Different studies have shown that $20 \%$ to $50 \%$ of angina patients undergoing coronary angiography have normal or near normal arteries, (non-obstructive coronary disease) [1-9]. These groups of patients were conventionally diagnosed as Cardiac Syndrome X. Today it is demonstrated that a large proportion of these patients have coronary microvascular dysfunction (CMD) [3]. $\mathrm{CMD}$ has gained more attention over the last 15 years as

\footnotetext{
*Correspondence: dr_esmaeili_n@yahoo.com

${ }^{1}$ Non-Communicable Diseases Research Center, Rafsanjan University of Medical Sciences, Building Number 1, Emam Ali Boulevard, P.O. Box: 77175-835, 7719617996 Rafsanjan, Iran

Full list of author information is available at the end of the article
}

a cardiac cause of morbidity and as critical as CAD. CMD diagnosed patients display high rates of hospitalization for unstable angina, myocardial infarction (MI) and heart failure $[7,10,11]$. Pathophysiology studies suggest that CMD develops by: (1) structural alterations including the remodeling of microvessels or microcircular rarefaction; or (2) functional abnormalities such as spasm or impaired dilatory function in endothelial or vascular smooth muscle cell (VSMC). The underlying mechanisms are the dysregulation of the related hormonal, metabolic or neurosympathetic (neural tone) stimuli [12-14]. CMD can occur as a primary condition in patients with no obstructive coronary disease or can exist in the setting of diffuse and focal epicardial coronary disease [15] or occur as a 
consequence of acute MI or other cardiac events leading to damage in coronary microcirculation (e.g. percutaneous coronary intervention). In case CMD and epicardial problems exists side by side, the diagnosis of CMD is challenging but clinically important for determining the prognosis of ischemic and angina patients. For example, diagnosis of CMD can explain why symptoms persist in some CAD patients following percutaneous coronary interventions (PCI) [15-17]. CMD diagnosis is often challenging and not as well established as diagnosis of CAD. Yet no imaging method is available to visualize vessels smaller than $500 \mu \mathrm{m}$ directly. Therefore, only indirect measurements of microvascular function are practiced in clinical settings today. Commonly, coronary flow reserve (CFR) is used as an indirect indicator of coronary microvascular function in the absence of CAD (normal or near normal angiography) [18-22]. CFR represents the capacity of coronary circulation to increase coronary blood flow (CBF) from basal levels to maximum in response to a vasodilatory stimulus. Therefore, CFR is proportional to blood flow in epicardial vessels plus microvasculature [23]. The reduced coronary flow reserve (CFR) manifested in CMD patients with no obstructive CAD (determined by normal angiography), is due to an impaired coronary vasodilation of microvasculature at higher demanding conditions of myocardium [23, 24].

Today, coronary microvascular function can be measured using invasive angiographic methods such as Dopplertipped coronary guidewire and wire-based thermodilution techniques. Additionally, non-invasive imaging technologies such as positron emission tomography (PET) cardiac magnetic resonance imaging (CMR) or transthoracic Doppler echocardiography of the left anterior descending coronary artery are applied to measure indexes of coronary microvascular function. Therefore, one complexity for diagnosis of CMD is that it requires technologies that may not be widely available [14, 25-27]. CMD is associated with conventional cardiac risk factors such as smoking, aging, obesity, diabetes mellitus, and hypertension $[18,28]$. However, growing number of publications point to the significant contribution of non-traditional risk factors in CMD development, including substance abuse (e.g., alcohol, opioids, cocaine). Here, we overview and highlight on the clinical and pathophysiological effects of substance abuse i.e., smoking, alcohol and opioids on CMD, with an aim to bring this topic to the attention of more researchers in the field.

\section{Search strategy}

In this literature review, a systematic search strategy was performed in electronic scientific databases PUBMED, Medline, Google Scholar using advanced search and all combinations of search terms. Search terms were selected based on the entry terms suggested by Medical
Subject Headings (MeSH). Title and abstracts were first screened based on relevance to the subject and the study was selected to be included in the review after assessing the full text for eligibility and relevance. Additionally, the reference and citing publication lists from the retrieved articles were checked to identify further relevant studies. The search time limit was since 1980 to date. We included only studies published in English. Our search terms include: (heart, coronary); (percutaneous coronary intervention, percutaneous coronary, revascularization, reperfusion, angioplasty); (smoking, tobacco, cigars, cigarette); (microvessel, Microvasculature, microvascular network, microvascular, microcirculation, small vessels, capillary, arteriole, angiogenesis, intimal proliferation, intimal neoplasia, neointimal, microvascular obstruction, MVO, coronary flow reserve, CFR, index of microvasculatory resistance, IMR); (Ethanol, alcohol, ethyl, EtOH, alcoholic, drinking, wine); (opioid, opiate, opium, morphine, amphetamine, methadone, analgesics) and (ischemia, infarction, MI).

\section{Impact of smoking on coronary microvasculature Impact of smoking on coronary microvasculature and stable CMD \\ Smoking pattern impact on the coronary microvascular function}

Epidemiological and case-control studies demonstrated chronic long-term smoking as one of the predictors of CMD in asymptomatic individuals [29-32] the nonobstructive coronary ischemic patients (no CAD) (stable CMD) [33, 34] as well as patients with vasospastic Angina [35] or CAD [36] background. These studies rely on the measured CFR and its stimulus-induced changes, due to unavailability of a direct technique to assess the coronary microvasculature status in vivo. Compared to long-term effects, the short-term chronic smoking assessed in healthy young smokers (with no evidence of CAD) did not affect the myocardial blood flow at resting conditions. However, smokers displayed a lower CFR in response to stress [29,31].

Acute smoking can also exert negative impact on coronary microvascular function (in habitual smokers or nonsmokers). Park et al. conducted a study on healthy young smokers and non-smokers, comparing CFR and the coronary vascular resistance index (CVRI) after a 4-h period of smoking abstinence. No significant difference between smokers and non-smokers was observed. However, after consumption of only two cigarettes in the smoking group, a considerable decline in CFR and an increase in CVRI were observed in the smokers [37].

On the other hand, the acute CFR declining effect was shown to be equivalent upon light (containing $0.6 \mathrm{mg}$ nicotine, $8 \mathrm{mg}$ tar, $9 \mathrm{mg}$ carbon monoxide) and regular cigarette 
smoking (containing $0.9 \mathrm{mg}$ nicotine, $=12 \mathrm{mg}$ tar, $12 \mathrm{mg}$ carbon monoxide) [38, 39]. On the contrary, one group found enhanced acute effect of high nicotine content cigarettes on CFR compared to the low content ones, showing a dose-dependent contribution of nicotine component of cigarettes in microvascular damaging effects of smoking [40].

Multiple studies have implicated passive smoking as a significant risk factor in CHD, being associated with higher rate of morbidity and mortality and poor outcome in CHD and acute coronary syndrome patients [41-49]. Additionally, an impairment of microvascular function and reactivity was supported by other studies indicating passive smoke exposure as a risk factor in CMD development $[50,51]$. On the other hand, passive smoking is associated with lower odds ratio of smoking cessation in CHD patients $[52,53]$. This is important due to the fact that smoking cessation is considered as a major preventive measure and management strategy to reduce mortality risk among CHD patients [54, 55 ] as well as patients with coronary microvascular dysfunction $[56,57]$.

Based on current information on the effects of different patterns of smoking on CMD (light vs. regular cigarette; active vs. passive smoking), evidence does not support one pattern over the other, emphasizing on the detrimental effects of smoking nevertheless. However, the limited number of studies on smoking-connected CMD, and particularly the small population size in most of these studies, necessitates conduction of large-scale research on this subject in the future.

\section{Mechanistic studies on the effects of smoking on coronary microvasculature in human subjects}

Evidence indicates that smoking affects coronary microvasculature via altering endothelial cells. Impaired coronary microvascular function in healthy young chronic smokers was observed under cold stress as an endothelium-dependent stimuli $[29,31]$ whereas dipyridamole which acts through endothelium-independent mechanisms, failed to affect microvascular function in healthy smokers [29]. The main mechanisms underlined in the literature for the smoking-induced vascular endothelial cell damage are oxidative stress, inflammation, impaired $\mathrm{Na}^{+} / \mathrm{K}^{+}$ATPase function (Fig. 1). Cigarette smoke contains several radical or non-radical oxidants including superoxide radicals $(\cdot \mathrm{O} 2-)$, hydroxyl radicals $(\cdot \mathrm{OH})$, and peroxides $(\mathrm{ROOH})$. Therefore, smoking can induce oxidative stress directly via its content and cause damage to coronary microvascular cells $[58,59]$. It was shown that vitamin $\mathrm{C}$ as a potent antioxidant has been demonstrated to normalize the impaired coronary microvascular function in chronic smokers, whereas it did not alter CFR in non-smokers at all [32]. In addition to the oxidative stress, smoking is considered as a potent proinflammatory factor in cardiac pathology. The reciprocal

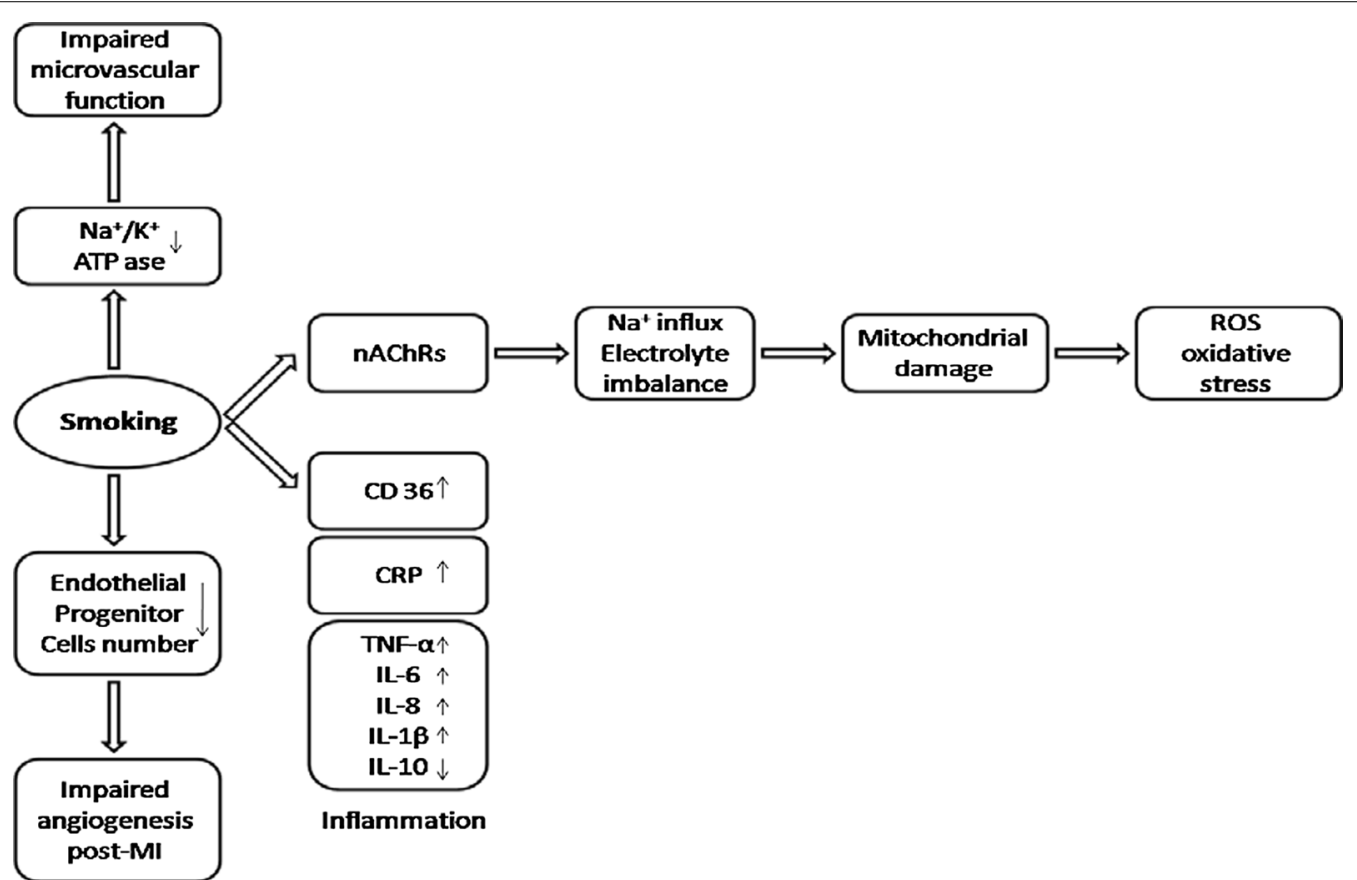

Fig. 1 Pathophysiology of smoking-triggered coronary microvascular damage. Summary of the underlying mechanisms of coronary microvascular damage caused by smoking 
stimulatory crosstalk between inflammation and oxidative stress has been widely discussed in the literature [60].

Multiple studies have linked chronic inflammatory disorders such as lupus, rheumatoid arthritis, and inflammatory bowel disease with higher risk of developing CMD [61-63]. Others confirmed this result finding a significant correlation between systemic inflammatory markers (mostly plasma CRP) and risk of CMD [64-66]. Recently, Schroder et al. assessed the differential blood protein profile of CMD patients and healthy volunteers. Interestingly, the main differentially expressed protein biomarkers they found to be associated with CMD were several pro-inflammatory factors, related to the TNF- $\alpha$-IL-6-CRP pathway [66]. Smoking is conventionally considered to induce inflammation based on studies who rely on self-reports on smoking status [67-70]. Recently, the National Health Survey in Korea conducted on 8655 men and 10,432 women reported a systemic pro-inflammatory effect of smoking. This study investigated the dose-dependent effect of cigarette smoking based on the cotinine concentration in the urine, on the systemic inflammation measured by leukocyte count [71]. In addition, they found higher plasma levels of inflammatory markers TNF$\alpha$, IL- 6 , IL- 8 and IL-1 $\beta$ in current smokers, while the antiinflammatory marker IL-10 showed reduction [58].

Rooks et al. measured CFR and different inflammatory markers (e.g., interleukin-6 and C-reactive protein), and oxidative status indicators (e.g., plasma hydroperoxides and the glutathione oxidation (GSSG/GSH ratio)) in healthy smoker and non-smoker twin couples. After adjusting the CFR levels to the inflammatory and oxidative stress indices, the declined level of CFR in smokers retained; which implicates the contribution of other underlying mechanisms to this difference, other than inflammation and ROS [30]. One such mechanism may be smoking-induced downregulation of ATPases [72]. Impaired microvascular reactivity and vasodilation in chronic smokers have been suggested to be caused at least partially because of the down-regulation of $\mathrm{Na}^{+} / \mathrm{K}^{+}$ATPase in coronary microcirculatory endothelial cells in smokers. Since, Quabain as an inhibitor of $\mathrm{Na}^{+} / \mathrm{K}^{+}$ ATPase, that normally induces vasodilation in coronary microcirculation, failed to act on chronic smokers' microcirculation [72].

\section{Mechanistic ex vivo and in vitro evidence on the effects of nicotine on coronary microvasculature}

Nicotinic acetylcholine receptors (nAChRs) are shown to express in coronary endothelial cells, and induce several pro-survival pathways upon normal physiologic stimulation [73]. However, their overstimulation in cells by chronic nicotine exposure causes aberrant microvascular dilatory functions via oxidative stress induction [74]. Induction of oxidative stress by overstimulation of nicotinic AChRs is due to their intrinsic cationic channel function [75]. Chronic nicotine exposure induces opening of these channels and an excessive influx of $\mathrm{Na}^{+}$ ions in to the cells. The following electrolyte imbalance results in overproduction of ROS and consequently cellular damage [76]. The effect of nicotine tested in vivo (rat model) demonstrated an impaired endothelial-dependent vascular function, concurrent with plasma increased level of inflammatory parameter CRP, as well as higher CD36, TNF $\alpha$ and IL1 $\beta$ in macrophages [77]. The proinflammatory effect of smoking and nicotine are on the other hand contradicted by findings of other in vivo and in vitro studies reporting that nicotine affects vascular endothelial cells and macrophages by reducing their production of inflammatory cytokines (e.g. TNF- $\alpha$ ), and consequently their capacity for leukocyte recruitment and adhesion [78, 79]. The reason for the contradictory results regarding the pro- or anti-inflammatory impact of nicotine is not understood yet, and warrants further assessment in the future.

\section{Impact of smoking on post-ischemic and $\mathrm{PCl}$-induced coronary microvascular injury Clinical studies on the impact of smoking on coronary microvasculature injury by reperfused myocardial infarction} Microvascular dysfunction as either microvascular intraluminal obstruction (MVO) or extravascular compression is one of the main non-reversible consequences of coronary ischemic reperfusion injury (IRI) caused by cardiac therapeutic interventions $[80,81]$. Ischemia causes mitochondrial damage, plasma membrane and cytoskeleton disintegrity, and impaired enzymatic activities in the cells by lowering the $\mathrm{pH}$ and ATP levels, inducing dysfunction of the ion exchange factors and electrolyte imbalance. Upon reperfusion and reversal of oxygen supply, the impaired ion exchangers, enzymes, cellular membrane and mitochondria result in reciprocal enhancement of oxidative stress and inflammation that may result in severe cell damage or cell death [82]. Therefore, knowing the risk factors that exacerbate this problem or on the contrary preconditioning or therapeutic mechanisms, which protect against the excessive oxidative damage, inflammation and cell death in post-MI conditions or by IRI are currently under special attention of researchers and clinicians. Although cigarette smoking is an independent risk factor for cardiovascular disease, studies have reported controversial results on the effects of smoking on the mortality rate and prognosis of patients who underwent reperfusion with a percutaneous coronary intervention (PCI) or the extent of post-MI injury (smoker's paradox phenomenon) which are previously reviewed elsewhere [55, 83-85]. Here we review studies which assessed the status of coronary microvasculature in these group of patients. Based on magnetic resonance $(\mathrm{CMR})$ analysis in reperfused ST-segment elevation 
myocardial infarction (STEMI) patients, smoking displayed no significant association with microvascular obstruction (MVO) [86, 87] and index of microvascular resistance (IMR) assessed by intra-coronary sensor angiography [88].

However, smoking was associated with intramyocardial haemorrhage (IMH) in post-PCI STEMI patients [86, 88 ] and in the presence of IMH, the protective effect of smoking on post-PCI cardiovascular health was abolished suggesting higher microvascular injury by post-ischemic reperfusion in smokers [86]. IMH is a marker of severe and irreversible injury to the coronary microvasculature by ischemia-reperfusion which results to extravasation of erythrocytes [89].

This result is challenged by another study using CMR is reperfused STEMI patients in another population, which did not find a significant association between smoking and the frequency of IMH [90]. The effect of smoking on endothelial progenitor cells (EPC) as necessary factors for repair and regeneration of microvasculature post-ischemia [91] was investigated by several studies. Smoking is shown to reduce the number of EPC, their adhesive capacity, and colony forming abilities [56, 91-93]. Therefore, if the damage to the coronary microcirculation is not irreversible (IMH), smoking may have beneficial impact on coronary microvascular regeneration post ischemia and reperfusion. Further research is warranted to assess this phenomenon in the future.

\section{Ex vivo and in vitro effects of smoking on post ischemic and $\mathrm{PCl}$-induced microvascular injury}

Animal studies indicate that nicotine has a pathologic angiogenic effect on coronary arteries and microvessels, and intimal hyperplasia post ischemia and in PCI [94, 95]. Nicotine angiogenic effects are mediated by nicotinic acetylcholine receptors in endothelial cells [95-97]. Neointimal formation induced by nicotine effect on VSMC post injury has been linked to ERK -Egr-1 signaling cascade, and the blockade of this pathway can revert the adverse effect of nicotine in coronary vascular remodeling [98].

\section{Impact of alcohol on coronary microvasculature Impact of alcohol on coronary microvasculature and stable CMD \\ Clinical impact of alcohol on the coronary microvascular function}

Detrimental health effects of alcohol include cardiometabolic complications which account for 33\% of death caused by alcohol [99]. Multiple studies demonstrated regular and irregular heavy drinking to markedly increase the risk of ischemic heart disease and hypertension [100-102]. However, the general effect of alcohol consumption on cardiovascular disease is considered to be complicated due to other reports which support a protective role for the low and moderate alcohol drinking in regard to the ischemic heart disease and MI [103, 104]. In this section we will review the current understanding of the impact of alcohol on coronary micro-vessels. Similar acute effect was observed for two moderate doses of red wine (not vodka or white wine) to improve CFR in healthy young individuals, indicating a vasodilatory and cardioprotective function. These doses of red wine correspond the amount of 0.5 and $1.0 \mathrm{~g} / \mathrm{kg}$ ethanol. The level of CFR increase was correlated with the level of antioxidant capacity of plasma induced by alcohol containing red wine. Improtantly, de-alcoholized red wine had no such effects. The CFR was measured by transthoracic Doppler echocardiography and right after bevarage drinking (acute effect of ethanol) [105]. This was contradicted by another study that measured CFR (by myocardial contrast echocardiography) in response to 1-2 weeks consumption of moderate dose of ethanol (red wine) and observed no change in CFR. The difference could be due to the fact that in the later study measurements were made at least $12 \mathrm{~h}$ after alcohol consumption; therefore, it cannot represent the acute effects of alcohol consumption, compared to the abovementioned studies which assessed CFR right after drinking [106].

\section{Mechanistic studies on the effects of alcohol on coronary microvasculature in human subjects}

Heavy alcohol has been shown to result in deleterious remodeling and ultra-structural alterations of the cardiac microcirculation, depicted by case-control studies that used histochemical staining, and microscopy on cardiac biopsies obtained from alcoholic patients (angina patients with no CAD) after their death. Briefly in regard to the underlying pathophysiological mechanisms of alcohol-induced damage, the results showed disorganization of the layers of the micro-vessel walls, edema, perivascular fibrosis, sclerosis, interstitial inflammation, the degeneration of endothelial cells and higher density of capillary network [107, 108] (Fig. 2).

\section{Mechanistic ex vivo and in vitro evidence on the effects of alcohol on coronary microvasculature}

Animal studies indicate increased coronary microvascular wall thickness and an enrichment of the ATP-hydrolyzing small-caliber micorvessels [109]. Morphometric analysis by electron microscopy confirmed structural changes in the endothelial cells of the capillaries but not the muscle cells. Numerical density of endothelial cells was enhanced, whereas the volume density did not show a significant alteration, indicative of the proliferation of endothelial cells [110].

Others reported widened peri-capillary distances resulting in enforced remodeling changes in the size and 


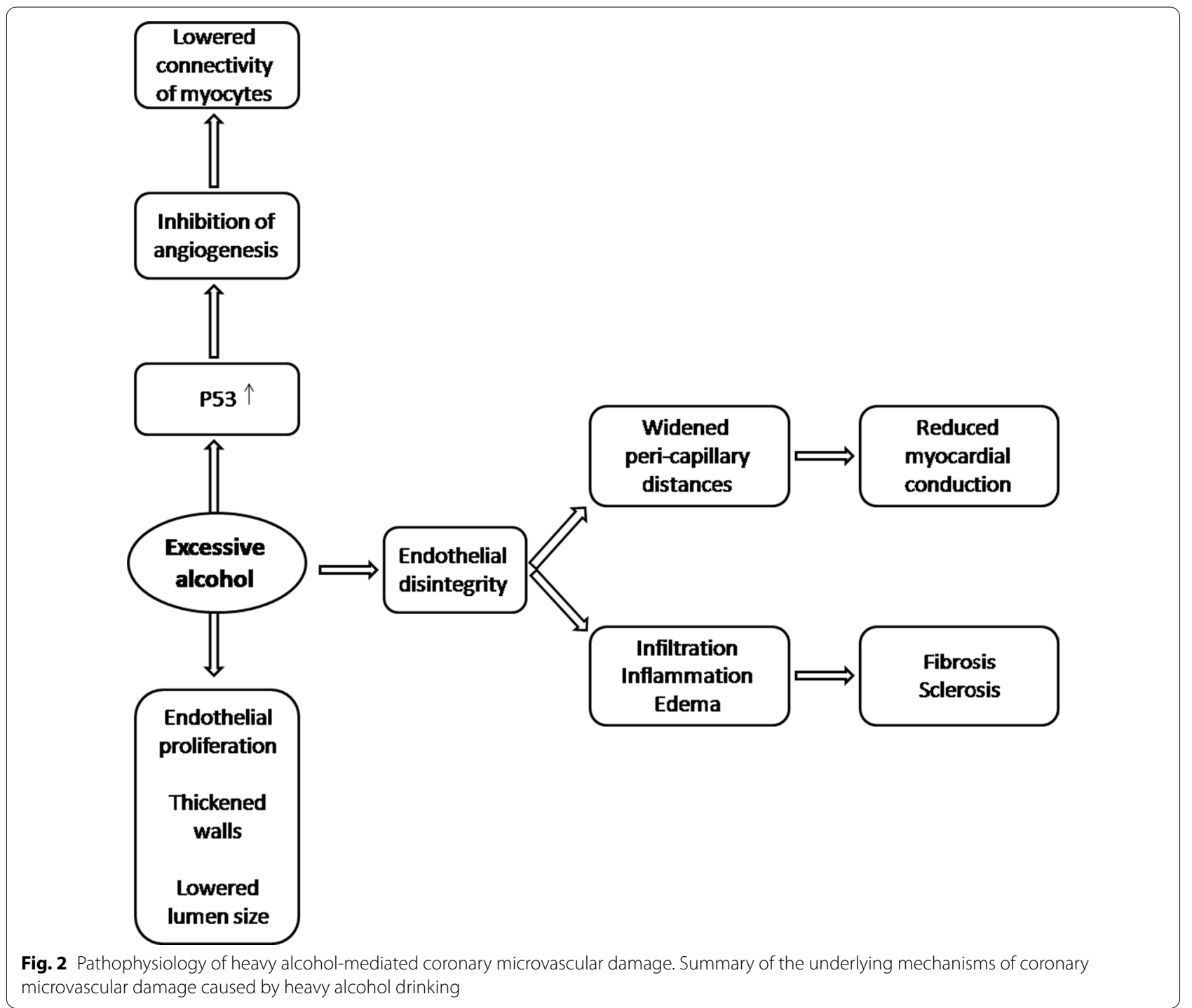

connectivity of cardiomyocytes, and subsequently impaired myocardial conduction in animal models [111]. Evidence suggests that alcohol-induced hypoxia-mimetic and metabolically demanding condition [112] in the endothelial cells, lead to the endothelial remodeling and degeneration. Consequently, the damage of the micro-vessel endothelial cells precipitates in an increased infiltration of fluids and metabolites to the vessel walls and the perivascular space, which in turn results in edema and inflammation [111, 113]. This mechanism consequently induces the reported deposit of higher levels of collagen, perivascular fibrosis and sclerosis, and declined conductivity [111].
Impact of alcohol on post-ischemic and $\mathrm{PCl}$-induced coronary microvascular injury Clinical studies on the impact of alcohol on coronary microvasculature injury by reperfused myocardial infarction Studies have shown better prognosis and lower mortality rate post MI [114-117] upon prior moderate but not heavy chronic alcohol consumption. In regard to PCI however, administration of a moderate dose of ethanol displayed an adverse effect on myocardial ischemic damage post PCI in STEMI patients [118]. Specific impact of moderate and heavy alcohol consumption on coronary microvascular 
function remains unfeatured as yet, warranting studies that assess the corresponding indices (e.g., CFR, MVO and IMR) in relation to beverage type, pattern and duration of alcohol consumption in MI patients.

\section{Ex vivo and in vitro effects of alcohol on post ischemic and $\mathrm{PCl}$-induced microvascular injury}

The angiogenesis occurs after myocardial injuries such as ischemia to provide oxygen and supplies for the regeneration process of the myocardium. In vivo study in rat model preconditioned with either a high, or a modest dose of alcohol before the induction of MI, showed that the angiogenesis is significantly increased upon moderate alcohol preconditioning; whereas it was reduced in excessive dose of alcohol consumption prior to MI [119]. The level of VEGF expression did not change upon intake of high ethanol doses, while endostatin was upregulated. Conversely, upon moderate alcohol intake, VEGF level was shown to be up-regulated, whereas endostatin expression significantly declined [119].

Angiogenic effects of moderate ethanol were concomitant with other beneficial cardio-protective effects including improved microvascular reactivity, endothelial function and myocardial perfusion in the ischemic regions of the myocardium [120, 121]. Interestingly, in the non-ischemic regions of myocardium distant from the ischemic territory, the blood flow and the endothelial microvascular reactivity showed no significant difference between the alcohol naïve and moderate EtOH group [120]. Moderate levels of ethanol is shown to positively regulate HIF- $1 \alpha$ mRNA expression as the transcription factor upstream of VEGF [122]; and the HIF- $1 \alpha$ protein is mainly stabilized upon hypoxic conditions while rapidly degraded at normal oxygen levels [123]. This could explain why the beneficial effects of alcohol only occur at ischemic regions, since HIF- $1 \alpha$ is expressed, but degraded (Fig. 3). The other suggested mechanisms for the angiogenic effects of moderate ethanol are the induction of proangiogenic factors including basic fibroblast growth factor (bFGF), transforming growth factor- $\beta 1$ (TGF- $\beta 1$ ) [124], and Notch/CBF-1/RBP-JK -Ang1/Tie2 or Notch/ Flk-1/KDR pathways in endothelial cells as indicated by in vitro studies $[125,126]$. On the other hand, inhibition of angiogenesis by high alcohol supplement may be attributed to the p53 upregulation following excessive alcohol consumption [127]. P53 is known to have anti-angiogenic features [128]. The other potential mechanisms could be inhibited VEGF signaling as shown to occur in the endothelial cells upon intoxication by high doses of ethanol [129]. It was shown that ethanol inhibits the VEGF signaling in vitro regardless of the level of VEGF expression, via suppressing the phosphorylation and the expression level of VEGF receptors [129].
Moderate chronic ethanol preconditioning was indicated to protect against IRI [130-132], whereas consumption of acute alcohol before IRI does not confer cardioprotection $[133,134]$.

Proposed mechanisms of alcohol-mediated IRI protection include PKC-E-ALDH activation, and mitoPTP (mitochondrial permeability transition pore) closing, which reduce the production and release of reactive oxygen species (ROS) [130, 131], as well as the VEGFinduced neovascularization which compensates for the IRI-induced cell death [132]. PKC- $\varepsilon$ activation and its cardiac mitochondrial translocation are triggered by moderate ethanol exposure. Inside mitochondria, it interacts with, and activates ALDH, which plays a critical role in reactive aldehydes detoxification and protection against mitochondrial-originated oxidative stress [130, 131, 135]. In addition, ALDH2 mitochondrial translocation inhibits opening of mitochondrial Permeability Transition Pore (mitoPTP), and thus leads to cardioprotective outcomes [136-138] MPTP is a mitochondrial membrane complex, which opens at highly stressed conditions of the cell (e.g. IRI, endotoxin, and anticancer agents), permitting the flow of the mitochondrial metabolites and ions, which leads to the induction of cell death [138]. Li etal., 2010 found that low concentration ethanol post-conditioning confers cardioprotection against IRI via inhibition of mitoPTP opening, associated with improved hemodynamics and smaller infarct size [136].

Further studies are essential to demonstrate the beneficial or harmful effects of alcohol-induced microvascular alterations, specifically in the setting of different cardiac diseases. Based on the studies available to this date, alcohol-induced microvascular remodeling can be directed toward a beneficial or disadvantageous path depending on the dose and the pattern of alcohol drinking.

\section{Opioids and coronary microvascular function Clinical effect of opioids on coronary microvasculature and CMD \\ Impact of opioids on coronary microvasculature and stable CMD}

Many studies have associated opioid abuse with higher risk of CAD [139-152]. Nonetheless, the effect of opium on the coronary microvascular dysfunction (CMD) is under-studied. A cross-sectional study undertaken in a city of Iran with almost $30 \%$ rate of opioid addiction in the rural areas [153-155], analyzed stable angina patients, with normal angiography, diagnosed with CMD. The results implicated that opium addiction acts as an independent risk factor in CMD development [155]. In 


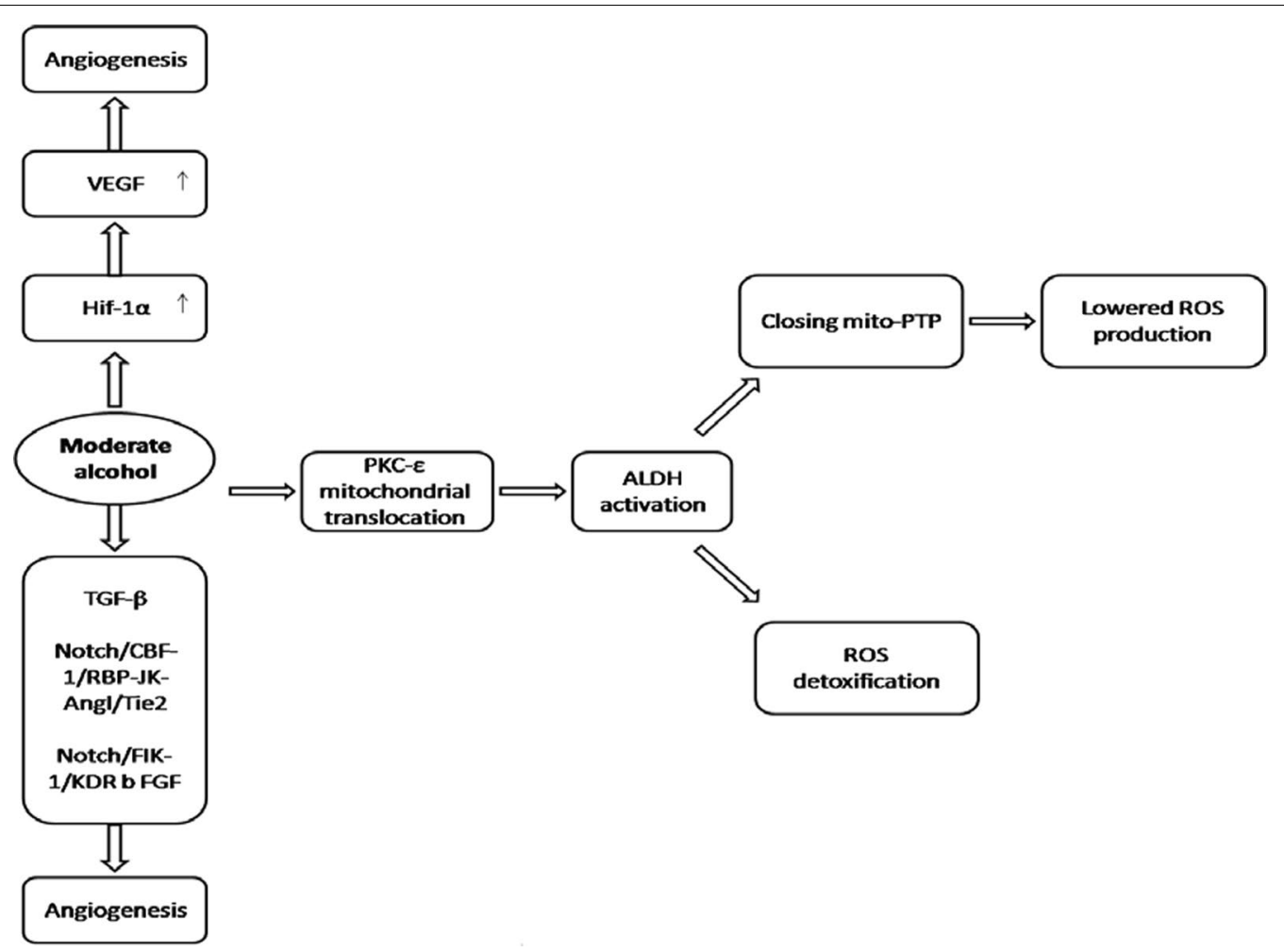

Fig. 3 Beneficial effects of moderate alcohol consumption on coronary microcirculation. Positive impact of moderate alcohol consumption or ethanol preconditioning on coronary microvascular integrity and function, protecting against post-Ml and PCI microvascular injuries

addition to opioid addiction, the effect of opioid-based anaesthetic substances on coronary microcirculation integrity showed microvascular perfusion impairment (long flow recovery times, and slower rate of oxygen resaturation) [156].

\section{Mechanistic ex vivo and in vitro evidence on the effects of opioid on coronary microvasculature}

Moreover, experiments in animal models indicated that morphine aggravates the destructive effect of hypertension on coronary microvessels, via inhibition of angiogenesis and lowering the capillary density, as well as by deteriorating endothelial cell function in NO (nitrite oxide) production [157].

\section{Impact of opioid on post-ischemic and $\mathrm{PCl}$-induced coronary microvascular injury Clinical studies on the impact of opioid on coronary} microvasculature injury by reperfused myocardial infarction Controversial reports on the impact of morphine and opioid agonists on mortality rate and myocardial damage post MI and PCI have been published suggesting a cardioprotective [158-160], adverse effect [161-163] or no significant change $[164,165]$. In reperfused STEMI patients, CMR analysis suggested contradictory results by different studies as no impact of morphine on microvascular obstruction (MVO) [165] versus an adverse effect exacerbating the myocardial and microvascular damage (MVO) post PCI [162]. Future clinical trials are warranted to assess the effect of opioids on coronary microvascular function in post MI and Post-PCI patients to determine the safety of using opioid analgesics for pain treatment of ischemic cardiovascular patients.

\section{Ex vivo and in vitro effects of opioid on post ischemic and $\mathrm{PCl}$-induced microvascular injury}

In vitro treatment of cultured endothelial cells and cardiac myocytes with morphine results in a marked reduction of VEGF expression. Subsequently the reduction of VEGF can lead to the inhibition of the neovascularization and the suppressed re-growth of the capillary network to restore the myocardial perfusion necessary to recover 


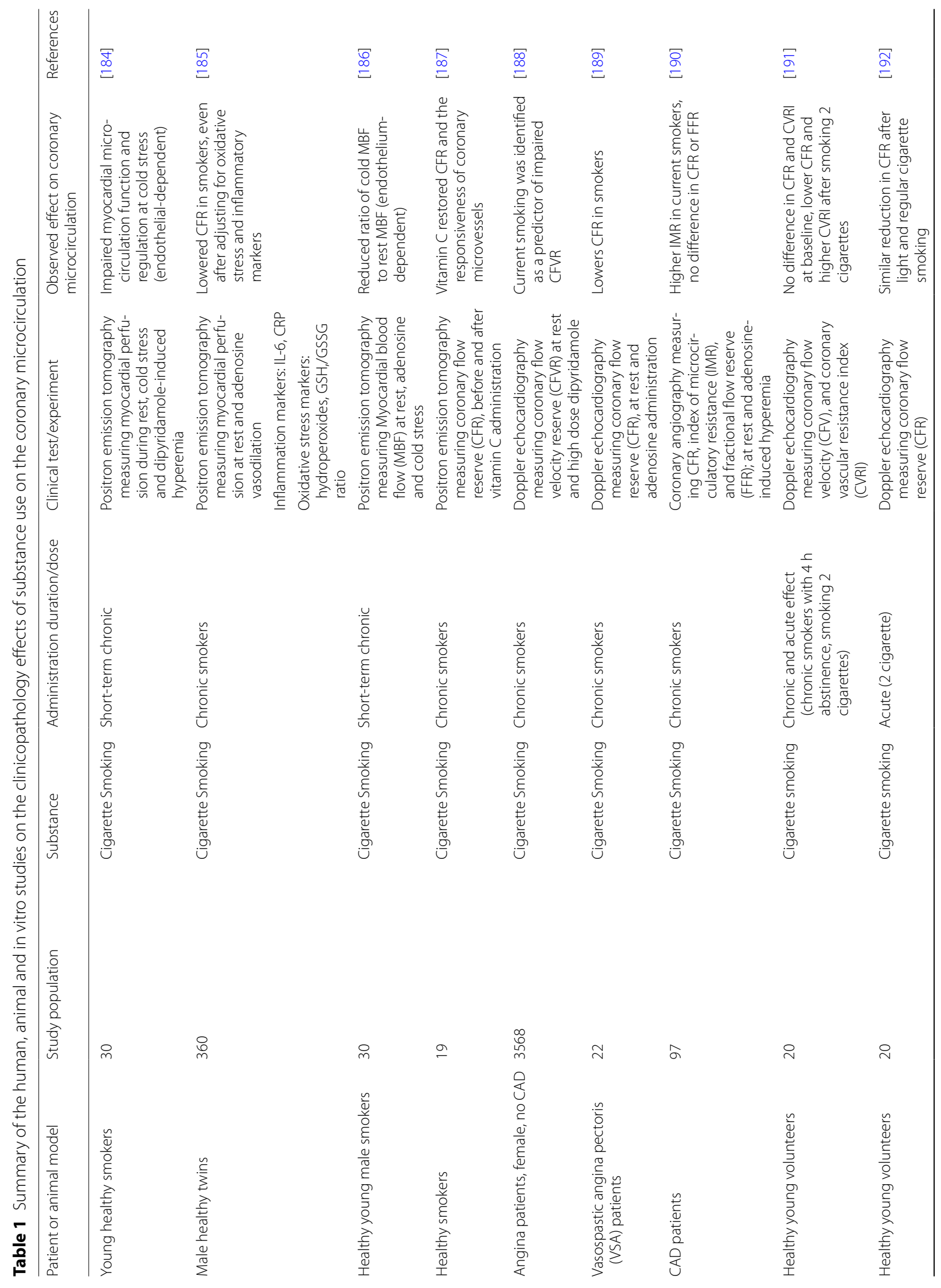


Jalali et al. BMC Cardiovasc Disord $\quad$ (2021) 21:185

Page 10 of 17

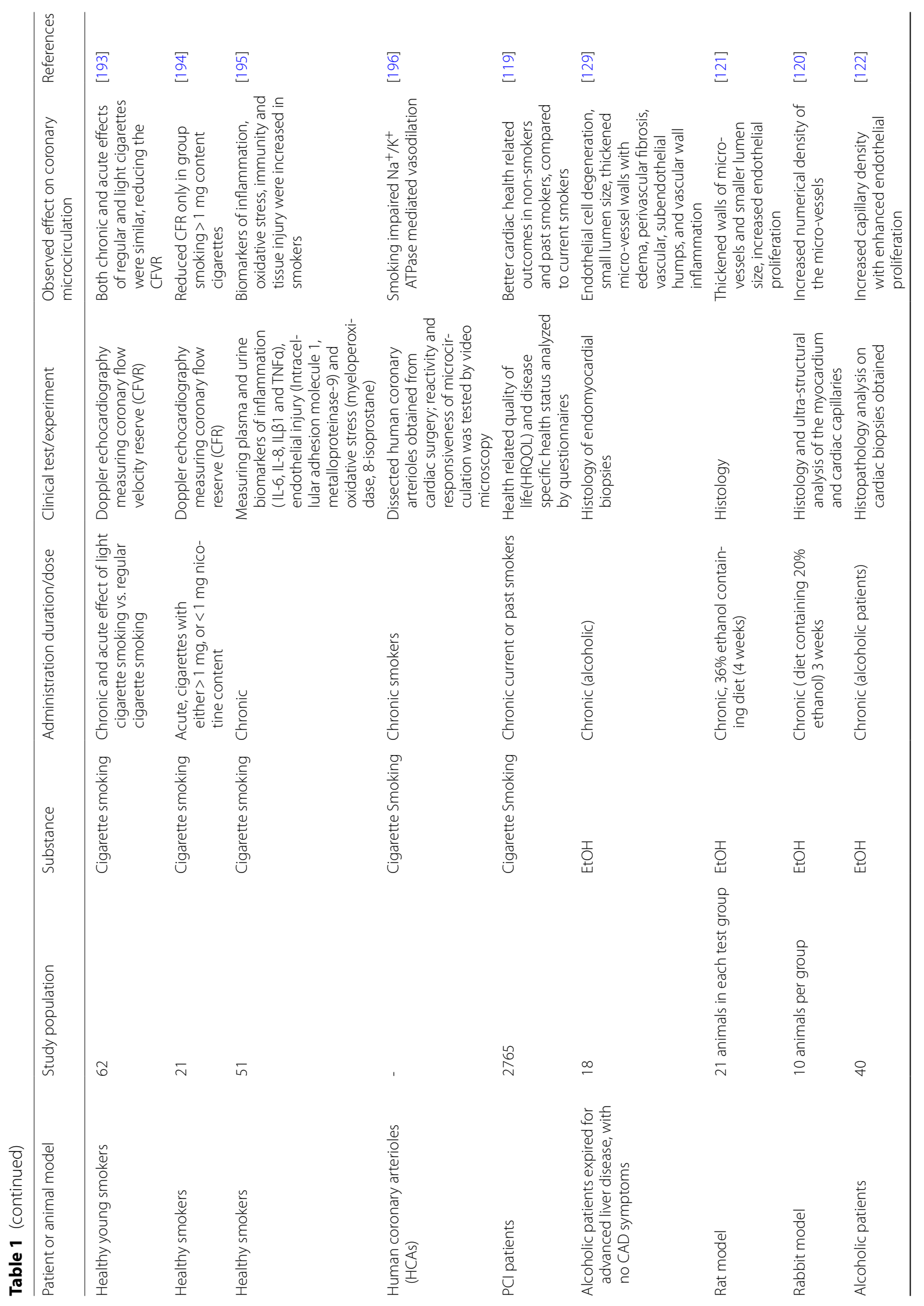




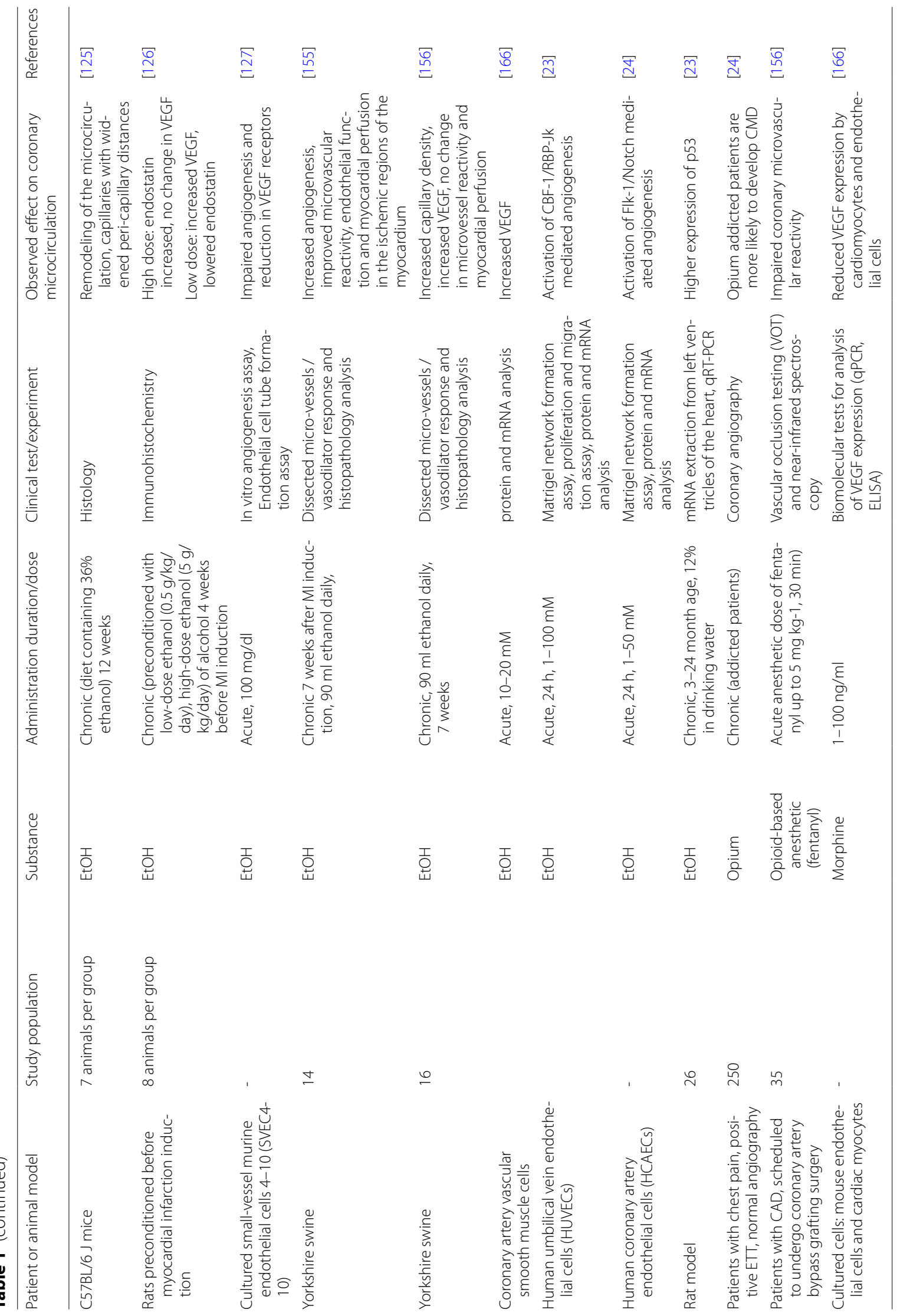


from ischemic injuries [166]. On the other hand, multiple studies suggest a cardioprotective role for opioids, indicating that the administration of opioid agonists such as morphine [167-171], fentanyl [172, 173] and methadone [174] attenuate the ischemic-triggered apoptosis and inflammation following myocardial ischemia, when used as a pre- or post-conditioning agent, or as pain treatment [170, 175-179]. Correspondingly, in vitro and ex vivo studies suggested that the enhanced opioid signaling diminished the cell death induced by ischemia-associated hypoxic injury [175, 180-183]. Summary of the human, animal and in vitro studies on the clinicopathology effects of substance use on the coronary microcirculation are presented in Table 1.

\section{Conclusion}

Overall, the presented evidence points to the importance of considering smoking, excessive alcohol use, and opioid addiction as independent risk factors in the development of the coronary microvascular disease. Moreover, evidence supports a cardioprotective role for moderate ethanol and opioids particularly against post-ischemic and intervention-mediated injuries to the coronary microcirculation. Almost $80 \%$ of the coronary vascular resistance is due to the microcirculation [23, 24]. Therefore the dysfunction of coronary microcirculatory network (CMD disease) can mainly impair the coronary blood perfusion, which results in cardiac damage [23, 24]. CMD has become a subject of attention among cardiologists and researchers over the last thirty years. Thus far, the studies have led to the identification of some of the mechanisms underlying the structural and functional impairment in the coronary microvasculature. Nevertheless, this is still a growing field and requires much further investigations. As of today, the diagnosis of CMD is still facing complications and misdiagnosis due to the technical limitations in imaging the coronary microcirculation, and the high cost and the invasiveness of the available clinical technologies. Therefore, more attention needs to be directed toward discovery of peripheral diagnostic markers for CMD, which are lacking.

Overall, more ultra-structural, molecular and histopathology assessments of the differential effects of various risk factors of CMD including smoking, alcohol, and drug addiction are essential. Combined with application of the most advanced imaging techniques for myocardial capillary network, future studies could lead to the development of novel specific diagnostic markers and therapeutic strategies for CMD, as well as preparation of accurate administration protocols for substances such as ethanol and opioid in preconditioning for ischemic cardiac disease in clinic.

\section{Abbreviations}

CVD: Cardiovascular diseases; AMI: Acute myocardial infarction; CAD: Coronary artery disease; CMD: Coronary microvascular dysfunction; CFR: Coronary flow reserve; CVRI: Coronary vascular resistance index; $\mathrm{PCI}$ : Percutaneous coronary intervention; VEGF: Vascular endothelial growth factor; IRI: Ischemic reperfusion injury; MVO: Microvascular intraluminal obstruction; mitoPTP: Mitochondrial permeability transition pore.

\section{Acknowledgements \\ Not Applicable}

\section{Authors' contributions}

EA carried out the design and conception of the article. The Execution and feasibility analysis of research was performed by EA; IZ, NS and KM collected and sorted out the data. JZ and EA analyzed and described the results. JZ wrote the thesis; EA and NS reviewed and amended the draft of the article. $E A$ and $J Z$ are supervisor, manager and responsible for the whole article. All authors read and approved of the final manuscript.

\section{Funding}

This project was supported by Rafsanjan University of Medical Sciences.

Availability of data and materials

All data used for this review study are available within the manuscript.

\section{Declarations}

Ethics approval and consent to participate

Not applicable.

\section{Consent for publication \\ Not applicable.}

\section{Competing interests}

This contribution received no funding and the authors declare no conflict of interest with respect to the present manuscript

\section{Author details}

${ }^{1}$ Non-Communicable Diseases Research Center, Rafsanjan University of Medical Sciences, Building Number 1, Emam Ali Boulevard, P.O. Box: 77175-835, 7719617996 Rafsanjan, Iran. ${ }^{2}$ Department of Clinical Biochemistry, School of Medicine, Rafsanjan University of Medical Sciences, Rafsanjan, Iran. ${ }^{3}$ Department of Pathology, Rafsanjan University of Medical Sciences, Rafsanjan, Iran. ${ }^{4}$ Department of Cardiology, School of Medicine, Rafsanjani University of Medical Sciences, Rafsanjan, Iran.

Received: 17 August 2020 Accepted: 7 April 2021

Published online: 15 April 2021

\section{References}

1. Shaw LJ, Shaw RE, Merz CNB, Brindis RG, Klein LW, Nallamothu B, et al. Impact of ethnicity and gender differences on angiographic coronary artery disease prevalence and in-hospital mortality in the American College of Cardiology-National Cardiovascular Data Registry. Circulation. 2008;117(14):1787.

2. Pacheco Claudio C, Quesada O, Pepine CJ, Noel Bairey Merz C. Why names matter for women: MINOCA/INOCA (myocardial infarction/ ischemia and no obstructive coronary artery disease). Clin Cardiol. 2018;41(2):185-93.

3. Pepine CJ, Ferdinand KC, Shaw LJ, Light-McGroary KA, Shah RU, Gulati $M$, et al. Emergence of nonobstructive coronary artery disease: a woman's problem and need for change in definition on angiography. J Am Coll Cardiol. 2015;66(17):1918-33.

4. Ong P, Athanasiadis A, Borgulya G, Mahrholdt H, Kaski JC, Sechtem U. High prevalence of a pathological response to acetylcholine testing in patients with stable angina pectoris and unobstructed coronary arteries: the ACOVA Study (Abnormal COronary VAsomotion in patients with 
stable angina and unobstructed coronary arteries). J Am Coll Cardiol. 2012;59(7):655-62.

5. Patel MR, Peterson ED, Dai D, Brennan JM, Redberg RF, Anderson HV et al. Low diagnostic yield of elective coronary angiography. J Am Coll Cardiol. 2010;362(10):886-95.

6. China J, Mitchell P, Gopinath B, Plant AJ, Kovoor P, Thiagalingam AJIH, et al. Gender differences in the severity and extent of coronary artery disease. IJC Heart Vascul. 2015;8:161-6.

7. Jespersen L, Hvelplund A, Abildstrøm SZ, Pedersen F, Galatius S, Madsen $J \mathrm{~K}$, et al. Stable angina pectoris with no obstructive coronary artery disease is associated with increased risks of major adverse cardiovascular events. Eur Heart J. 2012;33(6):734-44.

8. Members TF, Montalescot G, Sechtem U, Achenbach S, Andreotti F, Arden C, et al. 2013 ESC guidelines on the management of stable coronary artery disease: the Task Force on the management of stable coronary artery disease of the European Society of Cardiology. Eur Heart J. 2013;34(38):2949-3003.

9. Zimarino M, Cappelletti L, Venarucci V, Gallina S, Scarpignato M, Acciai $\mathrm{N}$, et al. Age-dependence of risk factors for carotid stenosis: an observational study among candidates for coronary arteriography. Atherosclerosis. 2001;159(1):165-73.

10. Kutty S, Bisselou Moukagna KS, Craft M, Shostrom V, Xie F, Porter TR. Clinical outcome of patients with inducible capillary blood flow abnormalities during demand stress in the presence or absence of angiographic coronary disease. Circ Cardiovasc Imaging. 2018;11(10):e007483.

11. Camici PG, Crea F. Microvascular angina: a women's affair? Am Heart Assoc.

12. Crea F, Lanza GA, Camici PG. Mechanisms of coronary microvascular dysfunction. Coronary microvascular dysfunction: Springer; 2014. p. 31-47.

13. Pries AR, Reglin BJ. Coronary microcirculatory pathophysiology: Can we afford it to remain a black box? Eur Heart J. 2017:38(7):478-88.

14. Camici PG, d'Amati G, Rimoldi O. Coronary microvascular dysfunction: mechanisms and functional assessment. Nat Rev Cardiol. 2015;12(1):48-62.

15. Sechtem U, Brown D, Godo S, Lanza GA, Shimokawa H, Sidik N. Coronary microvascular dysfunction in stable ischaemic heart disease (non-obstructive coronary artery disease and obstructive coronary artery disease). Cardiovasc Res. 2020;116(4):771-86.

16. Konijnenberg LS, Damman P, Duncker DJ, Kloner RA, Nijveldt R, van Geuns R-JM, et al. Pathophysiology and diagnosis of coronary microvascular dysfunction in ST-elevation myocardial infarction. CardiovascRes. 2020;116(4):787-805.

17. Crea F, Camici PG, Bairey Merz CN. Coronary microvascular dysfunction: an update. Eur Heart J. 2014;35(17):1101-11.

18. Chen C, Wei J, AlBadri A, Zarrini P, Merz CNB. Coronary microvascular dysfunction-epidemiology, pathogenesis, prognosis, diagnosis, risk factors and therapy. Circ J. 2016;16:1002.

19. Britten MB, Zeiher AM, Schächinger V. Microvascular dysfunction in angiographically normal or mildly diseased coronary arteries predicts adverse cardiovascular long-term outcome. Coronary Artery Dis. 2004:15(5):259-64.

20. Herscovici R, Sedlak T, Wei J, Pepine CJ, Handberg E, Bairey Merz CN Ischemia and no obstructive coronary artery disease (INOCA): What is the risk? J Am Heart Assoc. 2018;7(17):e008868.

21. Bairey Merz CN, Pepine CJ, Walsh MN, Fleg JL, Camici PG, Chilian WM, et al. Ischemia and no obstructive coronary artery disease (INOCA) developing evidence-based therapies and research agenda for the next decade. Circulation. 2017:135(11):1075-92.

22. Sara JD, Widmer RJ, Matsuzawa Y, Lennon RJ, Lerman LO, Lerman A. Prevalence of coronary microvascular dysfunction among patients with chest pain and nonobstructive coronary artery disease. JACC. 2015:8(11):1445-53.

23. Libby P. Braunwald's heart disease: a textbook of cardiovascular medicine. Philadelphia: Saunders/Elsevier; 2008.

24. De Lemos J, Omland T. Chronic coronary artery disease: a companion to Braunwald's heart disease E-book: Elsevier Health Sciences; 2017.

25. Feher A, Sinusas AJ. Quantitative assessment of coronary microvascular function: dynamic single-photon emission computed tomography, positron emission tomography, ultrasound, computed tomography and magnetic resonance imaging. Circulation. 2017;10(8):e006427.

26. Mathew RC, Bourque JM, Salerno M, Kramer CM. Cardiovascular imaging techniques to assess microvascular dysfunction. Cardiovasc Imaging. 2020;13(7):1577-90.

27. Sinha A, Rahman H, Perera D. Ischaemia without obstructive coronary artery disease: the pathophysiology of microvascular dysfunction. Curr Opin Cardiol. 2020;35(6):720-5.

28. Camici PG, Crea F. Coronary microvascular dysfunction. New Eng J Med. 2007;356(8):830-40

29. Madsen MM, Bøttcher M, Nielsen TT, Czernin J. Altered regulation of the myocardial microcirculation in young smokers. Cardiology. 2000;94(2):91-8.

30. Rooks C, Faber T, Votaw J, Veledar E, Goldberg J, Raggi P, et al. Effects of smoking on coronary microcirculatory function: a twin study. Atherosclerosis. 2011:215(2):500-6.

31. Iwado Y, Yoshinaga K, Furuyama H, Ito Y, Noriyasu K, Katoh C, et al. Decreased endothelium-dependent coronary vasomotion in healthy young smokers. Eur J Nucl Med Mol Imaging. 2002;29(8):984-90.

32. Kaufmann PA, Gnecchi-Ruscone T, Di Terlizzi M, Schäfers KP, Lüscher TF, Camici PG. Coronary heart disease in smokers: vitamin C restores coronary microcirculatory function. Circulation. 2000;102(11):1233-8.

33. Akasaka T, Hokimoto S, Sueta D, Tabata N, Sakamoto K, Yamamoto E, et al. Sex differences in the impact of CYP2C19 polymorphisms and low-grade inflammation on coronary microvascular disorder. Am J Physiol Heart Circ Physiol. 2016;310(11):H1494-500.

34. Mygind ND, Michelsen MM, Pena A, Frestad D, Dose N, Aziz A, et al. Coronary microvascular function and cardiovascular risk factors in women with angina pectoris and no obstructive coronary artery disease: the iPOWER study. J Am Heart Assoc. 2016;5(3):e003064.

35. Ashikaga T, Nishizaki M, Fujii H, Niki S, Maeda S, Yamawake N, et al. Examination of the microcirculation damage in smokers versus nonsmokers with vasospastic angina pectoris. Am J Cardiol. 2007;100(6):962-4.

36. Miyazaki T, Ashikaga T, Ohigashi H, Komura M, Kobayashi K, Isobe M. Impact of smoking on coronary microcirculatory resistance in patients with coronary artery disease. Int Heart J. 2015;56(1):29-36.

37. Park SM, Shim WJ, Song WH, Lim DS, Kim YH, Ro Y. Effects of smoking on coronary blood flow velocity and coronary flow reserve assessed by transthoracic Doppler echocardiography. Echocardiography. 2006;23(6):465-70.

38. Ciftci O, Caliskan M, Gullu H, Erdogan D, Topcu S, Guler O, et al. Acute effects of smoking light cigarettes on coronary microvascular functions. Clin Cardiol. 2009:32(4):210-4.

39. Gullu H, Caliskan M, Ciftci O, Erdogan D, Topcu S, Yildirim E, et al. Light cigarette smoking impairs coronary microvascular functions as severely as smoking regular cigarettes. Heart. 2007;93(10):1274-7.

40. Tanaka T, Oka Y, Tawara I, Sada T, Kira Y. Acute effects of nicotine content in cigarettes on coronary flow velocity and coronary flow reserve in men. Am J Cardiol. 1998;82(10):1275-8.

41. Health UDo, Services H. The health consequences of involuntary exposure to tobacco smoke: a report of the Surgeon General. Atlanta: US Department of Health and Human Services, Centers for Disease; 2006.

42. Oberg M, Jaakkola M, Prüss-Üstün A, Peruga A, Woodward A, Organization WH. Global estimate of the burden of disease from second-hand smoke. 2010

43. He J, Vupputuri S, Allen K, Prerost MR, Hughes J, Whelton PK. Passive smoking and the risk of coronary heart disease-a meta-analysis of epidemiologic studies. New Engl J Med. 1999;340(12):920-6.

44. Law MR, Morris J, Wald N. Environmental tobacco smoke exposure and ischaemic heart disease: an evaluation of the evidence. BMJ. 1997;315(7114):973-80.

45. Barnoya J, Glantz SA. Cardiovascular effects of secondhand smoke: nearly as large as smoking. Circulation. 2005:111(20):2684-98.

46. Steenland K. Risk assessment for heart disease and workplace ETS exposure among nonsmokers. Environ Health Perspect. 1999:107(suppl 6):859-63.

47. Law MR, Wald NJ. Environmental tobacco smoke and ischemic heart disease. Progress in cardiovascular diseases. Prog Cardiovasc Dis. 2003:46(1):31-8. 
48. Raupach T, Schäfer K, Konstantinides S, Andreas S. Secondhand smoke as an acute threat for the cardiovascular system: a change in paradigm. Eur Heart J. 2006;27(4):386-92.

49. Aronow WS. Effect of passive smoking on angina pectoris. New Engl J Med. 1978;299(1):21-4.

50. Argacha J-F, Adamopoulos D, Gujic M, Fontaine D, Amyai N, Berkenboom $\mathrm{G}$, et al. Acute effects of passive smoking on peripheral vascular function. Hypertension. 2008;51(6):1506-11.

51. Leone A, Giannini D, Bellotto C, Balbarini A. Passive smoking and coronary heart disease. Curr Vasc Pharmacol. 2004;2(2):175-82.

52. Prugger C, Wellmann J, Heidrich J, De Bacquer D, Perier M-C, Empana $J$-P, et al. Passive smoking and smoking cessation among patients with coronary heart disease across Europe: results from the EUROASPIRE III survey. Eur Heart J. 2014;35(9):590-8.

53. Prugger C, Wellmann J, Heidrich J, De Bacquer D, De Backer G, Périer $\mathrm{M}-\mathrm{C}$, et al. Readiness for smoking cessation in coronary heart disease patients across Europe: results from the EUROASPIRE III survey. Eur J Prev Cardiol. 2015;22(9):1212-9.

54. Critchley JA, Capewell SS. Smoking cessation for the secondary prevention of coronary heart disease. Cochrane database of systematic reviews. 2000(2).

55. Wilson K, Gibson N, Willan A, Cook D. Effect of smoking cessation on mortality after myocardial infarction: meta-analysis of cohort studies. Arch Intern Med. 2000;160(7):939-44.

56. Kondo T, Hayashi M, Takeshita K, Numaguchi Y, Kobayashi K, lino S, et al. Smoking cessation rapidly increases circulating progenitor cells in peripheral blood in chronic smokers. Arterioscleros Thromb Vas Biol. 2004;24(8):1442-7.

57. Samim A, Nugent L, Mehta PK, Shufelt C, Merz CNB. Treatment of angina and microvascular coronary dysfunction. Curr Treat Options Cardiovasc Med. 2010;12(4):355-64.

58. Khan NA, Lawyer G, McDonough S, Wang Q, Kassem NO, Kas-Petrus F, et al. Systemic biomarkers of inflammation, oxidative stress and tissue injury and repair among waterpipe, cigarette and dual tobacco smokers. Tobacco Control. 2020:29(Suppl 2):s102-9.

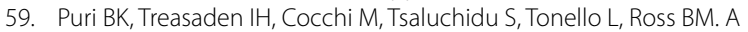
comparison of oxidative stress in smokers and non-smokers: an in vivo human quantitative study of n-3 lipid peroxidation. BMC Psychiatry. 2008;8(S1):S4

60. Dandekar A, Mendez R, Zhang K. Cross talk between ER stress, oxidative stress, and inflammation in health and disease. Stress responses: Springer; 2015. p. 205-14

61. Tona F, Serra R, Di Ascenzo L, Osto E, Scarda A, Fabris R, et al. Systemic inflammation is related to coronary microvascular dysfunction in obese patients without obstructive coronary disease. Nutr Metab Cardiovasc Dis. 2014:24(4):447-53.

62. Caliskan Z, Gokturk HS, Caliskan M, Gullu H, Ciftci O, Ozgur GT, et al. Impaired coronary microvascular and left ventricular diastolic function in patients with inflammatory bowel disease. Microvasc Res. 2015;97:25-30.

63. Recio-Mayoral A, Mason JC, Kaski JC, Rubens MB, Harari OA, Camici PG. Chronic inflammation and coronary microvascular dysfunction in patients without risk factors for coronary artery disease. Eur Heart J. 2009;30(15):1837-43.

64. Recio-Mayoral A, Rimoldi OE, Camici PG, Kaski JC. Inflammation and microvascular dysfunction in cardiac syndrome X patients without conventional risk factors for coronary artery disease. JACC. 2013;6(6):660-7.

65. Suzuki M, Shimizu H, Miyoshi A, Takagi Y, Sato S, Nakamura Y. Association of coronary inflammation and angiotensin II with impaired microvascular reperfusion in patients with ST-segment elevation myocardial infarction. Int J Cardiol. 2011;146(2):254-6.

66. Schroder J, Mygind ND, Frestad D, Michelsen M, Suhrs HE, Bove KB, et al. Pro-inflammatory biomarkers in women with non-obstructive angina pectoris and coronary microvascular dysfunction. IJC Heart VasC. 2019;24:100370

67. Ugur MG, Kutlu R, Kilinc I. The effects of smoking on vascular endothelial growth factor and inflammation markers: a case-control study. Clin Respir J. 2018;12(5):1912-8.

68. Lee J, Taneja V, Vassallo R. Cigarette smoking and inflammation: cellular and molecular mechanisms. J Dent Res. 2012;91(2):142-9.
69. Yanbaeva DG, Dentener MA, Creutzberg EC, Wesseling G, Wouters EF. Systemic effects of smoking. Chest. 2007;131(5):1557-66.

70. Luetragoon T, Rutqvist LE, Tangvarasittichai O, Andersson BÅ, Löfgren S, Usuwanthim $\mathrm{K}$, et al. Interaction among smoking status, single nucleotide polymorphisms and markers of systemic inflammation in healthy individuals. Immunology. 2018;154(1):98-103.

71. Choi W-J, Lee J-W, Cho AR, Lee Y-J. Dose-dependent toxic effect of cotinine-verified tobacco smoking on systemic inflammation in apparently healthy men and women: a nationwide population-based study. Int J Environ Res Public Health. 2019;16(3):503.

72. Miura H, Toyama K, Pratt PF, Gutterman DD. Cigarette smoking impairs $\mathrm{Na}+-\mathrm{K}+-$ ATPase activity in the human coronary microcirculation. Am J Physiol Heart Circ Physiol. 2011;300(1):H109-17.

73. Smedlund K, Tano JY, Margiotta J, Vazquez G. Evidence for operation of nicotinic and muscarinic acetylcholine receptor-dependent survival pathways in human coronary artery endothelial cells. J Cell Biochem. 2011;112(8):1978-84.

74. Mayhan WG, Sharpe GM. Chronic exposure to nicotine alters endothelium-dependent arteriolar dilatation: effect of superoxide dismutase. J Appl Physiol. 1999;86(4):1126-34.

75. Changeux J-P. The nicotinic acetylcholine receptor: the founding father of the pentameric ligand-gated ion channel superfamily. J Biol Chem. 2012;287(48):40207-15.

76. Krautwurst D, Seifert R, Hescheler J, Schultz G. Formyl peptides and ATP stimulate $\mathrm{Ca} 2+$ and $\mathrm{Na}+$ inward currents through non-selective cation channels via G-proteins in dibutyryl cyclic AMP-differentiated $\mathrm{HL}-60$ cells. Involvement of $\mathrm{Ca} 2+$ and $\mathrm{Na}+$ in the activation of $\beta$-glucuronidase release and superoxide production. Biochem J. 1992;288(3):1025-35.

77. Liu C, Zhou M-S, Li Y, Wang A, Chadipiralla K, Tian R, et al. Oral nicotine aggravates endothelial dysfunction and vascular inflammation in diet-induced obese rats: role of macrophage TNFa. PLOS ONE. 2017;12(12):e0188439.

78. Saeed RW, Varma S, Peng-Nemeroff T, Sherry B, Balakhaneh D, Huston J, et al. Cholinergic stimulation blocks endothelial cell activation and leukocyte recruitment during inflammation. J Exp Med. 2005;201(7):1113-23.

79. Báez-Pagán CA, Delgado-Vélez M, Lasalde-Dominicci JA. Activation of the macrophage a7 nicotinic acetylcholine receptor and control of inflammation. J Neuroimmune Pharmacol. 2015;10(3):468-76.

80. Hausenloy DJ, Yellon DM. Myocardial ischemia-reperfusion injury: a neglected therapeutic target. J Clin Investig. 2013;123(1):92-100.

81. Sezer M, van Royen N, Umman B, Bugra Z, Bulluck H, Hausenloy DJ, et al. Coronary microvascular injury in reperfused acute myocardial infarction: a view from an integrative perspective. J Am Heart Assoc. 2018:7(21):e009949.

82. Neri M, Riezzo I, Pascale N, Pomara C, Turillazzi E. Ischemia/reperfusion injury following acute myocardial infarction: a critical issue for clinicians and forensic pathologists. Mediat Inflamm. 2017;2017.

83. Ma W-Q, Wang Y, Sun X-J, Han X-Q, Zhu Y, Yang R, et al. Impact of smoking on all-cause mortality and cardiovascular events in patients after coronary revascularization with a percutaneous coronary intervention or coronary artery bypass graft: a systematic review and meta-analysis. Coronary Artery Dis. 2019;30(5):367-76.

84. Mulcahy R. Influence of cigarette smoking on morbidity and mortality after myocardial infarction. Brit Heart J. 1983;49(5):410.

85. Aune E, Røislien J, Mathisen M, Thelle DS, Otterstad JE. The "smoker's paradox" in patients with acute coronary syndrome: a systematic review. BMC Med. 2011;9(1):97.

86. Symons R, Masci PG, Francone M, Claus P, Barison A, Carbone I, et al. Impact of active smoking on myocardial infarction severity in reperfused ST-segment elevation myocardial infarction patients: the smoker's paradox revisited. Eur Heart J. 2016;37(36):2756-64.

87. Redfors B, Furer A, Selker HP, Thiele H, Patel MR, Chen S, et al. Effect of Smoking on Outcomes of Primary PCI in Patients With STEMI. J Am Coll Cardiol. 2020;75(15):1743-54

88. Haig C, Carrick D, Carberry J, Mangion K, Maznyczka A, Wetherall K, et al. Current smoking and prognosis after acute ST-segment elevation myocardial infarction: new pathophysiological insights. JACC. 2019;12(6):993-1003. 
89. Basso C, Corbetti F, Silva C, Abudureheman A, Lacognata C, Cacciavillani $L$, et al. Morphologic validation of reperfused hemorrhagic myocardial infarction by cardiovascular magnetic resonance. Am J Cardiol. 2007;100(8):1322-7.

90. Reinstadler SJ, Eitel C, Fuernau G, de Waha S, Desch S, Mende M, et al. Association of smoking with myocardial injury and clinical outcome in patients undergoing mechanical reperfusion for ST-elevation myocardial infarction. Eur Heart J Cardiovasc Imaging. 2017;18(1):39-45.

91. Leal V, Ribeiro CF, Oliveiros B, António N, Silva S. Intrinsic vascular repair by endothelial progenitor cells in acute coronary syndromes: an update overview. Stem Cell Rev Rep. 2019;15(1):35-47.

92. Kaur S, Jayakumar K, Kartha CC. The potential of circulating endothelial progenitor cells to form colonies is inversely proportional to total vascular risk score in patients with coronary artery disease. Indian Heart J. 2007;59(6):475-81.

93. Ivanova V, Kostin S, Popovich I, Chebanu N, Kobets V, Popovich M. Qualitative and quantitative changes of circulating in blood endotheliocyte precursor cells in patients with hypercholesterolemia. Kardiologiia. 2010;50(12):27-31.

94. Ruixing $Y$, Qi B, Tangwei $L$, Jiaquan $L$. Effects of nicotine on angiogenesis and restenosis in a rabbit model. Cardiology. 2007;107(2):122-31.

95. Heeschen C, Jang JJ, Weis M, Pathak A, Kaji S, Hu RS, et al. Nicotine stimulates angiogenesis and promotes tumor growth and atherosclerosis. Nat Med. 2001;7(7):833-9.

96. Villablanca AC. Nicotine stimulates DNA synthesis and proliferation in vascular endothelial cells in vitro. J Appl Physiol. 1998;84(6):2089-98.

97. Heeschen C, Weis M, Cooke JP. Nicotine promotes arteriogenesis. J Am Coll Cardiol. 2003;41(3):489-96.

98. Vazquez-Padron Rl, Mateu D, Rodriguez-Menocal L, Wei Y, Webster KA, Pham SM. Novel role of Egr-1 in nicotine-related neointimal formation. Cardiovasc Res. 2010;88(2):296-303.

99. Organization WH. Global status report on alcohol and health 2018: World Health Organization; 2019.

100. Roerecke M, Rehm J. Alcohol consumption, drinking patterns, and ischemic heart disease: a narrative review of meta-analyses and a systematic review and meta-analysis of the impact of heavy drinking occasions on risk for moderate drinkers. BMC Med. 2014;12(1):182

101. Roerecke M, Rehm J. Chronic heavy drinking and ischaemic heart disease: a systematic review and meta-analysis. Open Heart. 2014; 1 (1):e000135.

102. Roerecke M, Rehm J. Irregular heavy drinking occasions and risk of ischemic heart disease: a systematic review and meta-analysis. Am 」 Epidemiol. 2010;171(6):633-44.

103. Roerecke M, Rehm J. The cardioprotective association of average alcohol consumption and ischaemic heart disease: a systematic review and meta-analysis. Addiction. 2012;107(7):1246-60.

104. Leong DP, Smyth A, Teo KK, McKee M, Rangarajan S, Pais P, et al. Patterns of alcohol consumption and myocardial infarction risk: observations from 52 countries in the INTERHEART case-control study. Circulation. 2014;113:7627.

105. Shimada K, Watanabe H, Hosoda K, Takeuchi K, Yoshikawa J. Effect of red wine on coronary flow-velocity reserve. The Lancet. 1999:354(9183):1002.

106. Kaul S, BelcikT, Kalvaitis S, Jayaweera AR, Choi S-W, Wei K. Effect of modest alcohol consumption over 1-2 weeks on the coronary microcirculation of normal subjects. Eur J Echocardiogr. 2010;11(8):683-9.

107. Factor SM. Intramyocardial small-vessel disease in chronic alcoholism. Am Heart J. 1976;92(5):561-75.

108. Vaideeswar P, Chaudhari C, Rane S, Gondhalekar J, Dandekar S. Cardiac pathology in chronic alcoholics: a preliminary study. J Postgrad Med. 2014;60(4):372.

109. Herrmann H, Morvai V, Ungváry G, Norden C, Mühlig P. Long-term effects of ethanol on coronary microvessels of rats. MicrocircEndoth Lymph. 1984;1(5):589-610.

110. Mall G, Mattfeldt T, Rieger P, Volk B, Frolov V. Morphometric analysis of the rabbit myocardium after chronic ethanol feeding-early capillary changes. Basic Res Cardiol. 1982;77(1):57-67.

111. Lai Y-J, Hung C-L, Hong R-C, Tseng Y-M, Lin C-I, Ko Y-S, et al. Slow conduction and gap junction remodeling in murine ventricle after chronic alcohol ingestion. J Biomed Sci. 2011;18(1):72.
112. Steiner JL, Lang CH. Etiology of alcoholic cardiomyopathy: mitochondria, oxidative stress and apoptosis. Int J Biochem Cell Biol. 2017:89:125-35.

113. Chen Y, Davis-Gorman G, Watson RR, McDonagh PF. Ethanol modulates coronary permeability to macromolecules in murine AIDS. Alcohol Alcohol. 2002;37(6):555-60.

114. Mukamal KJ, Maclure M, Muller JE, Sherwood JB, Mittleman MA. Prior alcohol consumption and mortality following acute myocardial infarction. JAMA. 2001:285(15):1965-70.

115. Pai JK, Mukamal KJ, Rimm EB. Long-term alcohol consumption in relation to all-cause and cardiovascular mortality among survivors of myocardial infarction: the health professionals follow-up study. Eur Heart J. 2012;33(13):1598-605.

116. Rosenbloom JI, Mukamal KJ, Frost LE, Mittleman MA. Alcohol consumption patterns, beverage type, and long-term mortality among women survivors of acute myocardial infarction. Am J Cardiol. 2012;109(2):147-52.

117. Churchill EN, Disatnik M-H, Budas GR, Mochly-Rosen D. Ethanol for cardiac ischemia: the role of protein kinase c. Therap Adv Cardiovasc Dis. 2008;2(6):469-83.

118. Niccoli G, Altamura L, Fabretti A, Lanza GA, Biasucci LM, Rebuzzi AG, et al. Ethanol abolishes ischemic preconditioning in humans. J Am Coll Cardiol. 2008;51(3):271-5.

119. Zhang $Y$, Yuan $H$, Sun $Y$, Wang $Y$, Wang A. The effects of ethanol on angiogenesis after myocardial infarction, and preservation of angiogenesis with rosuvastatin after heavy drinking. Alcohol. 2016;54:27-32.

120. Elmadhun NY, Sabe AA, Lassaletta AD, Sellke FW. Ethanol promotes new vessel growth in remote nonischemic myocardium. JSurgRes. 2015;193(2):536-42.

121. Lassaletta AD, Elmadhun NY, Liu Y, Feng J, Burgess TA, Karlson NW, et al. Ethanol promotes arteriogenesis and restores perfusion to chronically ischemic myocardium. Circulation. 2013;128(11 suppl 1):S136-43.

122. Gu J-W, Elam J, Sartin A, Li W, Roach R, Adair TH. Moderate levels of ethanol induce expression of vascular endothelial growth factor and stimulate angiogenesis. Am J Physiol Regul Integr Comp Physiol. 2001;281(1):R365-72.

123. Lee J-W, Bae S-H, Jeong J-W, Kim S-H, Kim K-W. Hypoxia-inducible factor (HIF-1) a: its protein stability and biological functions. Exp Mol Med. 2004;36(1):1.

124. Gavin TP, Wagner PD. Acute ethanol increases angiogenic growth factor gene expression in rat skeletal muscle. J Appl Physiol. 2002:92(3):1176-82.

125. Morrow D, Cullen JP, Cahill PA, Redmond EM. Ethanol stimulates endothelial cell angiogenic activity via a Notch-and angiopoietin1-dependent pathway. Cardiovasc Res. 2008;79(2):313-21.

126. Morrow D, Hatch E, Hamm K, Cahill PA, Redmond EM. Flk-1/KDR mediates ethanol-stimulated endothelial cell Notch signaling and angiogenic activity. J Vasc Res. 2014;51(4):315-24.

127. Jänkälä H, Eriksson PC, Eklund K, Sarviharju M, Härkönen M, Mäki T. Effect of chronic ethanol ingestion and gender on heart left ventricular p53 gene expression. AlcoholClinExpRes. 2005;29(8):1368-73.

128. Teodoro JG, Evans SK, Green MR. Inhibition of tumor angiogenesis by p53: a new role for the guardian of the genome. J Mol Med. 2007:85(11):1175-86.

129. Radek KA, Kovacs EJ, Gallo RL, DiPietro LA. Acute ethanol exposure disrupts VEGF receptor cell signaling in endothelial cells. Am J Physiol Heart Circ Physiol. 2008;295(1):H174.

130. Churchill EN, Disatnik M-H, Mochly-Rosen D. Time-dependent and ethanol-induced cardiac protection from ischemia mediated by mitochondrial translocation of $\varepsilon P K C$ and activation of aldehyde dehydrogenase 2. J Mol Cell Cardiol. 2009;46(2):278-84.

131. Budas GR, Disatnik M-H, Chen C-H, Mochly-Rosen D. Activation of aldehyde dehydrogenase 2 (ALDH2) confers cardioprotection in protein kinase C epsilon (PKC $\varepsilon$ ) knockout mice. J Mol Cell Cardiol. 2010;48(4):757-64.

132. Louboutin J-P, Marusich E, Gao E, Agrawal L, Koch WJ, Strayer DS. Ethanol protects from injury due to ischemia and reperfusion by increasing vascularity via vascular endothelial growth factor. Alcohol. 2012;46(5):441-54. 
133. Hale S, Kloner R. Ethanol does not exert myocardial preconditioning in an intact rabbit model of ischemia/reperfusion. Heart Dis. 2001;3(5):293-6.

134. Itoya M, Morrison JD, Downey HF. Effect of ethanol on myocardial infarct size in a canine model of coronary artery occlusion-reperfusion. Myocardial Ischemia and Reperfusion: Springer; 1998. p. 35-41.

135. Budas GR, Disatnik M-H, Mochly-Rosen D. Aldehyde dehydrogenase 2 in cardiac protection: a new therapeutic target? Trends Cardiovasc Med. 2009;19(5):158-64.

136. Li Z, Jiang C, Xia M, Ye H, Guan S, Gao Q. Activation of mitochondrial aldehyde dehydrogenase 2 and inhibition of mitochondrial permeability transition pore involved in cardioprotection of ethanol postconditioning. Zhejiang da xue xue bao Yi xue ban JZhejiang UnivMedSci. 2010;39(6):566-71.

137. Lim SY, Davidson SM, Hausenloy DJ, Yellon DM. Preconditioning and postconditioning: the essential role of the mitochondrial permeability transition pore. Cardiovasc Res. 2007;75(3):530-5.

138. Morciano G, Bonora M, Campo G, Aquila G, Rizzo P, Giorgi C, et al. Mechanistic role of MPTP in ischemia-reperfusion injury. Mitochondrial Dynamics in Cardiovascular Medicine: Springer; 2017. p. 169-89.

139. Masoudkabir F, Sarrafzadegan N, Eisenberg MJ. Effects of opium consumption on cardiometabolic diseases. Nat Rev Cardiol. 2013;10(12):733-40

140. Marmor M, Penn A, Widmer K, Levin Rl, Maslansky R. Coronary artery disease and opioid use. Am J Cardiol. 2004;93(10):1295-7.

141. Sadeghian S, Darvish S, Davoodi G, Salarifar M, Mahmoodian M, Fallah $\mathrm{N}$, et al. The association of opium with coronary artery disease. Eur J Cardiovasc Prev Rehabil. 2007;14(5):715-7.

142. Sadeghian S, Graili P, Salarifar M, Karimi AA, Darvish S, Abbasi SH. Opium consumption in men and diabetes mellitus in women are the most important risk factors of premature coronary artery disease in Iran. Int J Cardiol. 2010;141(1):116-8

143. Gensini GG. A more meaningful scoring system for determining the severity of coronary heart disease. Am J Cardiol. 1983;51(3):606.

144. Masoomi M, Ramezani MA, Karimzadeh H. The relationship of opium addiction with coronary artery disease. Int J Prev Med. 2010;1(3):182.

145. Masoumi M, Shahesmaeili A, Mirzazadeh A, Tavakoli M, Ali AZ. Opium addiction and severity of coronary artery disease: a case-control study. J Res Med Sci. 2010;15(1):27

146. Hosseini SA, Salehi A. The relationship between coronary risk factors and coronary artery involvement based on angiogrpahy findings. Koomesh. 2012;14(1):7-12.

147. Rezvani MR, Ghandehari K. Is opium addiction a risk factor for ischemic heart disease and ischemic stroke? J Res Med Sci. 2012;17(10):958.

148. AZIMZADE SB, Gholamreza Y, Narooey S. A case-control study of effect of opium addiction on myocardial infarction. 2005.

149. Niaki MRK, Hamid M, Farshidi F, Mohammadpour M, Omran MTS. Evaluation of the role of opium addiction in acute myocardial infarction as a risk factor. Caspian J Intern Med. 2013;4(1):585.

150. Safaei N. Outcomes of coronary artery bypass grafting in patients with a history of opiate use. Pak J Biol Sci. 2008;11(22):2594.

151. Li L, Setoguchi S, Cabral H, Jick S. Opioid use for noncancer pain and risk of myocardial infarction amongst adults. J Intern Med. 2013;273(5):511-26.

152. Khademi H, Malekzadeh R, Pourshams A, Jafari E, Salahi R, Semnani S, et al. Opium use and mortality in Golestan Cohort Study: prospective cohort study of 50000 adults in Iran. BMJ. 2012;344:e2502.

153. Ahmad Jamalizadeh ZK, Nadimi AE, Nejadghaderi M, Saeidi A, Porkarami A. Prevalence of smoking and high blood pressure, two major risk factors for non-communicable diseases: the SuRF NCD (surveillance of risk factors of non-communicable disease) report 2012. J Cardiovasc Thorac Res. 2016;8(4):183.

154. Poustchi H, Eghtesad S, Kamangar F, Etemadi A, Keshtkar A-A, Hekmatdoost $A$, et al. prospective epidemiological research studies in IrAN (The PERSIAN Cohort): Rationale, objectives and design. American journal of epidemiology. 2017

155. Nadimi AE, Amiri FP, Fathollahi MS, Hassanshahi G, Ahmadi Z, Sayadi AR. Opium addiction as an independent risk factor for coronary microvascular dysfunction: a case-control study of 250 consecutive patients with slow-flow angina. Int J Cardiol. 2016;219:301-7.
156. Vandenbulcke L, Lapage KG, Vanderstraeten KV, De Somer FM, De Hert SG, Moerman AT. Microvascular reactivity monitored with nearinfrared spectroscopy is impaired after induction of anaesthesia in cardiac surgery patients: an observational study. Eur J Anaesthesiol. 2017;34(10):688-94

157. Zeinivand M, Pourshanazari A, Hassanshahi G. Coronary angiogenesis during morphine and nicotine withdrawal in two-kidney one clip hypertensive (2K1C) rats. Bratislavske lekarske listy. 2015;116(9):554-9.

158. Murphy GS, Szokol JW, Marymont JH, Avram MJ, Vender JS. Opioids and cardioprotection: the impact of morphine and fentanyl on recovery of ventricular function after cardiopulmonary bypass. J Cardiothorac Vasc Anesth. 2006;20(4):493-502

159. Tanaka K, Kersten J, Riess ML. Opioid-induced cardioprotection. Current Pharm Des. 2014:20(36):5696-705.

160. Rentoukas I, Giannopoulos G, Kaoukis A, Kossyvakis C, Raisakis K, Driva $\mathrm{M}$, et al. Cardioprotective role of remote ischemic periconditioning in primary percutaneous coronary intervention: enhancement by opioid action. JACC. 2010:3(1):49-55

161. Meine T, Roe M, Chen A, Whitling D. Association of intravenous morphine use and outcomes in acute coronary syndromes: results from the CRUSADE quality improvement initiative. AmHeart J. 2006;30(1):123.

162. de Waha S, Eitel I, Desch S, Fuernau G, Lurz P, Urban D, et al. Intravenous morphine administration and reperfusion success in ST-elevation myocardial infarction: insights from cardiac magnetic resonance imaging. Clin Res Cardiol. 2015;104(9):727-34

163. Bellandi B, Zocchi C, Xanthopoulou I, Scudiero F, Valenti R, Migliorini $A$, et al. Morphine use and myocardial reperfusion in patients with acute myocardial infarction treated with primary PCI. Int J Cardiol. 2020;221:567-71.

164. Bonin M, Mewton N, Roubille F, Morel O, Cayla G, Angoulvant D, et al. Effect and safety of morphine use in acute anterior ST-segment elevation myocardial infarction. J Am Heart Assoc. 2018;7(4):e006833.

165. Eitel I, Wang J, Stiermaier T, Fuernau G, Feistritzer H-J, Joost A, et al. Impact of morphine treatment on infarct size and reperfusion injury in acute reperfused ST-elevation myocardial infarction. J Clin Med. 2020;9(3):735.

166. Balasubramanian S, Ramakrishnan S, Charboneau R, Wang J, Barke RA, Roy S. Morphine sulfate inhibits hypoxia-induced vascular endothelia growth factor expression in endothelial cells and cardiac myocytes. J Mol Cell Cardiol. 2001;33(12):2179-87.

167. Schultz JEJ, Hsu AK, Gross GJ. Morphine mimics the cardioprotective effect of ischemic preconditioning via a glibenclamide-sensitive mechanism in the rat heart. Circ Res. 1996;78(6):1100-4.

168. Wang T-L, Chang H, Hung C-R, Tseng Y-Z. Attenuation of neutrophil and endothelial activation by intravenous morphine in patients with acute myocardial infarction. Am J Cardiol. 1997:80(12):1532-5.

169. Wang T-L, Chang H, Hung C-R, Tseng Y-Z. Morphine preconditioning attenuates neutrophil activation in rat models of myocardial infarction. Cardiovasc Res. 1998:40(3):557-63.

170. Groban L, Vernon JC, Butterworth J. Intrathecal morphine reduces infarct size in a rat model of ischemia-reperfusion injury. Anesth Anal. 2004;98(4):903-9.

171. Lu Y, Dong C, Yu J, Li L. Role of central and peripheral opioid receptors in the cardioprotection of intravenous morphine preconditioning. Irish J Med Sci. 2011;180(4):881.

172. Kato R, Ross S, Foex P. Fentanyl protects the heart against ischaemic injury via opioid receptors, adenosine A1 receptors and KATP channel linked mechanisms in rats. Brit J Anaesth. 2000;84(2):204-14.

173. Kato $R$, Foex P. Fentanyl reduces infarction but not stunning via $\delta$-opioid receptors and protein kinase $C$ in rats. Brit J Anaesth. 2000;84(5):608-14.

174. Gross ER, Hsu AK, Gross GJ. Acute methadone treatment reduces myocardial infarct size via the $\delta$-opioid receptor in rats during reperfusion. Anesth Anal. 2009:109(5):1395.

175. Okubo S, Tanabe Y, Takeda K, Kitayama M, Kanemitsu S, Kukreja RC, et al. Ischemic preconditioning and morphine attenuate myocardial apoptosis and infarction after ischemia-reperfusion in rabbits: role of $\delta$-opioid receptor. Am J PhysioL. 2004;287(4):H1786-91.

176. Ela C, Barg J, Vogel Z, Hasin Y, Eilam Y. Distinct components of morphine effects on cardiac myocytes are mediated by the $k$ and $\delta$ opioid receptors. J Mol Cell Cardiol. 1997:29(2):711-20. 
177. Ludwig LM, Patel HH, Gross GJ, Kersten JR, Pagel PS, Warltier DC. Morphine enhances pharmacological preconditioning by isofluranerole of mitochondrial KATPchannels and opioid receptors. Anesthesiol JAmSoc Anesthesiol. 2003;98(3):705-11.

178. Weihrauch D, Krolikowski JG, Bienengraeber M, Kersten JR, Warltier DC, Pagel PS. Morphine enhances isoflurane-induced postconditioning against myocardial infarction: the role of phosphatidylinositol-3-kinase and opioid receptors in rabbits. Anesth Anal. 2005;101(4):942-9.

179. Schultz JJ, Hsu AK, Gross GJ. Ischemic preconditioning and morphineinduced cardioprotection involve the delta ( $\delta$ )-opioid receptor in the intact rat heart. J Mol Cell Cardiol. 1997;29(8):2187-95.

180. Tanaka K. Kersten rJ, L Riess M 2014 Opioid-induced cardioprotection. Curr Pharma Des. 2014;20(36):5696-705.

181. Romano MA, Seymour EM, Berry JA, McNish RA, Bolling SF. Relative contribution of endogenous opioids to myocardial ischemic tolerance. J Surg Res. 2004;118(1):32-7.

182. Takasaki Y, Wolff RA, Chien GL, van Winkle DM. Met5-enkephalin protects isolated adult rabbit cardiomyocytes via $\delta$-opioid receptors. Am J Physiol Heart Circ Physiol. 1999;277(6):H2442-50.

183. Chien GL, Van Winkle DM. Naloxone blockade of myocardial ischemic preconditioning is stereoselective. J Mol Cell Cardiol. 1996;28(9):1895-900.

184. Miyazaki T, Ashikaga T, Ohigashi H, Komura M, Kobayashi K, Isobe M. Impact of smoking on coronary microcirculatory resistance in patients with coronary artery disease. Int Heart J. 2015;56(1):29-36.

185. Park SM, Shim WJ, Song WH, Lim DS, Kim YH, Ro YM. Effects of smoking on coronary blood flow velocity and coronary flow reserve assessed by transthoracic Doppler echocardiography. Echocardiography. 2006;23(6):465-70.

186. Ciftci O, Caliskan M, Gullu H, Erdogan D, Topcu S, Guler O, et al. Acute effects of smoking light cigarettes on coronary microvascular functions. Clin Cardiol. 2009;32(4):210-4.

187. Gullu H, Caliskan M, Ciftci O, Erdogan D, Topcu S, Yildirim E, et al. Light cigarette smoking impairs coronary microvascular functions as severely as smoking regular cigarettes. Heart. 2007;93(10):1274-7.
188. Tanaka T, Oka Y, Tawara I, Sada T, Kira Y. Acute effects of nicotine content in cigarettes on coronary flow velocity and coronary flow reserve in men. Am J Cardiol. 1998;82(10):1275-8.

189. Chaumont M, De Becker B, Zaher W, Culié A, Deprez G, Mélot C, et al. Differential effects of e-cigarette on microvascular endothelial function, arterial stiffness and oxidative stress: a randomized crossover trial. Sci Rep. 2018;8(1):10378.

190. Khan NA, Lawyer G, McDonough S, Wang Q, Kassem NO, Kas-Petrus F, et al. Systemic biomarkers of inflammation, oxidative stress and tissue injury and repair among waterpipe, cigarette and dual tobacco smokers. Tobacco Control. 2019:tobaccocontrol-2019-054958.

191. Miura H, Toyama K, Pratt PF, Gutterman DD. Cigarette smoking impairs Na+-K+-ATPase activity in the human coronary microcirculation. Am J Physiol Heart Circ Physiol. 2010;300(1):H109-17.

192. Jang J-S, Buchanan DM, Gosch KL, Jones PG, Sharma PK, Shafiq A, et al. Association of smoking status with health-related outcomes after percutaneous coronary intervention. CircCardiovascInterven. 2015;8(5):e002226.

193. Factor SM. Intramyocardial small-vessel disease in chronic alcoholism. Am Heart J. 1976:92(5):561-75.

194. Herrmann H, Morvai V, Ungváry G, Norden C, Mühlig P. Long-term effects of ethanol on coronary microvessels of rats. Microcirc Endoth Lymph. 1984;1(5):589-610.

195. Vaideeswar P, Chaudhari C, Rane S, Gondhalekar J, Dandekar S. Cardiac pathology in chronic alcoholics: a preliminary study. J Postgrad Med. 2014;60(4):372.

196. Lai Y-J, Hung C-L, Hong R-C, Tseng Y-M, Lin C-I, Ko Y-S, et al. Slow conduction and gap junction remodeling in murine ventricle after chronic alcohol ingestion. J Biomed Sci. 2011;18(1):72.

\section{Publisher's Note}

Springer Nature remains neutral with regard to jurisdictional claims in published maps and institutional affiliations.
Ready to submit your research? Choose BMC and benefit from:

- fast, convenient online submission

- thorough peer review by experienced researchers in your field

- rapid publication on acceptance

- support for research data, including large and complex data types

- gold Open Access which fosters wider collaboration and increased citations

- maximum visibility for your research: over $100 \mathrm{M}$ website views per year

At $\mathrm{BMC}$, research is always in progress.

Learn more biomedcentral.com/submissions 